\title{
Spatio-Temporal Pattern of Land Degradation along the China-Mongolia Railway (Mongolia)
}

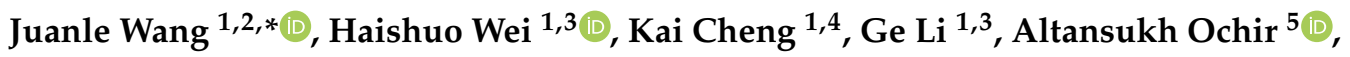 \\ Lingling Bian ${ }^{1,3}$, Davaadorj Davaasuren ${ }^{6} \mathbb{D}$, Sonomdagva Chonokhuu ${ }^{5}$ and \\ Elbegjargal Nasanbat ${ }^{7}$ (D) \\ 1 State Key Laboratory of Resources and Environmental Information System, \\ Institute of Geographic Sciences and Natural Resources Research, Chinese Academy of Sciences, \\ Beijing 100101, China; weihs@lreis.ac.cn (H.W.); chengk@lreis.ac.cn (K.C.); lig@lreis.ac.cn (G.L.); \\ bianll@1reis.ac.cn (L.B.) \\ 2 Jiangsu Center for Collaborative Innovation in Geographical Information Resource Development and \\ Application, Nanjing 210023, China \\ 3 School of Civil and Architectural Engineering, Shandong University of Technology, Zibo 255049, China \\ 4 College of Geoscience and Surveying Engineering, University of Chinese Academy of Sciences, \\ Beijing 100049, China \\ 5 Department of Environment and Forest Engineering, National University of Mongolia, Ulaanbaatar 210646, \\ Mongolia; altansukh22@yahoo.com (A.O.); sonomdagva@seas.num.edu.mn (S.C.) \\ 6 Department of Geography, National University of Mongolia, Ulaanbaatar 14201, Mongolia; \\ davaadorj@num.edu.mn \\ 7 Information and Research Institute of Meteorology, Hydrology and Environment, Ulaanbaatar 15160, \\ Mongolia; n_elbegjargal@yahoo.com \\ * Correspondence: wangjl@igsnrr.ac.cn; Tel.: +86-10-6488-8016
}

Received: 18 March 2019; Accepted: 7 May 2019; Published: 13 May 2019

\begin{abstract}
The increasingly serious problem of land degradation has a direct impact on the ecosystem and sustainable development in Mongolia. The influence of land degradation on the main China-Mongolia-Russia traffic arteries is currently unclear and poses a risk to the construction of transportation infrastructure. In this study, for the first time, we obtained land cover data from 1990, 2010, and 2015, at a 30 m, resolution based on the Landsat Thematic Mapper (TM) and Landsat Operational Land Imager (OLI) images along the China-Mongolia railway (Mongolia section). We then analyzed the change in the obtained land cover data using the geographic information system (GIS) spatial analysis technology to obtain the land pattern and development trend of this region. Results showed that the newly-increased degraded land was distributed mainly in the center of the region and tended to expand northward. The joint effect of natural and socioeconomic factors resulted in land degradation. We speculated that the significant temperature fluctuation and the decrease in rainfall were the inducing factors. Population migration, overgrazing, infrastructure construction, unreasonable mineral exploitation, and rapid urbanization aggravate the degree of land degradation. It is thus necessary to use a broader view to observe patterns of desertification and variations in regions along the Railway facing its sustainable development.
\end{abstract}

Keywords: land degradation pattern; remote sensing; monitoring; driving force

\section{Introduction}

The Siberian Railway is an important trunk railway traversing across and connecting China, Mongolia, and Russia and passing through Continental Europe [1]. The China-Mongolia Railway (Mongolian section, hereinafter "the Railway") linking China and Mongolia was built between 1947 
and 1955 . The Railway bears $80 \%$ of the freight volume and $30 \%$ of the passenger volume within the Mongolian territory. In September and October 2013, Chinese President Jinping Xi put forward the cooperation initiatives of building "the Silk Road Economic Belt" and "21st-Century Maritime Silk Road", which are collectively known as the "Belt and Road Initiative" [2]. In June 2016, the heads of China, Russia, and Mongolia witnessed the signing of the Outline for the Construction of China-Mongolia-Russia Economic Corridor in Tashkent, which was the first multilateral cooperation outline of the "Belt and Road Initiative" [3]. The Railway is located at the intersection of the China-Mongolia-Russia economic corridor and Mongolia's Steppe Road [4]. It has historically been the main traffic artery among China, Mongolia, and Russia, and with the implementation of the Belt and Road Initiative, will become the core of traffic infrastructure in the China-Mongolia-Russia Economic Corridor.

Mongolia is a hotspot of global land degradation [5]. Land degradation leads to loss of available grassland resources, decreased biological production, and deterioration of the ecological environment [6]. During 1961-2006, the numbers of plant species in Mongolia's forest steppe, real grassland, mountain meadow, desert steppe, and desert decreased by $50.0 \%, 44.7 \%, 30.3 \%, 23.8 \%$, and $26.7 \%$, respectively. The numbers of plant species continued to decrease annually, while grassland also continued to be severely degraded [7]. By 2009, at least $72 \%$ of Mongolia's land had been degraded, with continued expansion of the scope of desertification [8]. With the continuous aggravation of land degradation and the steady advances made in the China-Mongolia-Russia Economic Corridor construction, it is urgent to monitor, analyze, and diagnose patterns and dynamic variations of land degradation along the Railway.

To date, limited data monitoring of land degradation has been conducted in the China-Mongolia-Russia Economic Corridor regions. Some scholars have conducted large-scale studies with coarse resolution data on the Mongolian Plateau and its near regions. For example, Liu et al. determined the fractional vegetation cover (FVC), modified soil adjusted vegetation index (MSAVI), Albedo, land surface temperature (LST), and temperature vegetation dryness index (TVDI) through inversion of national oceanic and atmospheric administration (NOAA) data and moderate-resolution imaging spectroradiometer (MODIS) data, and accordingly, built a quantitative desertification remote-sensing monitoring index system. Furthermore, they provided data on the distribution of desertification land in China and Central Asia for 1995-2001 at a spatial resolution of $1 \mathrm{~km}$ [9]. Unulbart et al. extracted information about desertification on the Mongolian Plateau from MODIS data, and analyzed the spatial distribution pattern of desertification and its variation trend on the Mongolian Plateau for the years 2001-2010 [10]. He found that moderate desertification land was expanding from northwestern Mongolia to Dundgovi and Dornogovi in southeastern Mongolia, and that severe and extremely severe desertification lands were mainly distributed in southern Dundgovi, Omnogovi, and Dornogovi. Through inversion of MODIS data, Zhuo determined the normalized difference vegetation index (NDVI), MSAVI, FVC, LST, and drought index to generate a status map of desertification in the Mongolia Plateau for 2006 at a spatial resolution of $1 \mathrm{~km}$ [11]. He found that moderate desertification land was distributed mainly in sandy regions (e.g., Khorchin sand land), severe desertification land was distributed mainly in the outer Altai Gobi and Tengger deserts, and extremely severe desertification land was concentrated in the Central Gobi and Badain Jaran deserts. In such studies, data were acquired with coarse spatial resolution and very little data were acquired after 2010. With the continuous improvement in spectral resolution, time and spatial resolution of remote sensing data, people began to utilize more sensors to discover more accurate land degradation monitoring results [12-14]. In particular, the Landsat series data have been widely used [15-17]. Wang et al. used Landsat TM and Landsat 8 images to monitor the recent trend of aeolian desertification in the Qinghai Lake basin in the north-east Qinghai-Tibet Plateau [18]. They discussed the spatio-temporal evolutions of the landscape patterns of regional aeolian desertification land (ADL). Munkhnasan et al. extracted desertification information on the Hogno Khaan Nature Reserve in Mongolia based on Landsat TM/ETM + data, obtained a status map of desertification with a resolution of $30 \mathrm{~m}$ in the region, and completed the desertification dynamic analysis between 1990 and 2011 [19]. 
Noyola et al. assessed the progress of desertification of the southern edge of the Chihuahuan Desert based on Landsat TM images [20]. They found that desertification in the region has a slightly increasing trend. From this, we can determine that there are few studies on land degradation and desertification in Mongolia based on Landsat series data.

With the implementation of the Belt and Road Initiative and the China-Mongolia-Russia Economic Corridor program, it is urgently necessary to analyze the land degradation patterns within this region at a higher spatial resolution and to employ a longer time sequence. This is to provide the necessary data and decision support for the sustainable development of the China-Mongolia-Russia transportation area. Through object-oriented remote-sensing image interpretation, in this study, we acquire data for different types of land covers in the regions along the Railway for 1990, 2010, and 2015 at a resolution of $30 \mathrm{~m}$. We then analyze the change in land cover types for these years by using the GIS spatial analysis technology, and acquire land degradation patterns occurring over the most recent 25 years. Finally, we aim to ascertain the driving factors behind land degradation in these regions and present corresponding suggestions.

\section{Materials and Methods}

\subsection{Study Area}

The Railway has a total length of approximately $1526.35 \mathrm{~km}$; it starts in Beijing and ends in Ulaanbaatar, and extends to the Ulan-Ude Station in Russia, which belongs to Russia's Siberian Railway. The Railway stretches from south to north within the Mongolian territory and passes through the following major cities: Zamyn Uud (a frontier port between China and Mongolia), Sainshand (the fourth largest city in Mongolia), Bor Undur (a world-class fluorite production area) [21], Ulaanbaatar (Mongolia's capital and the largest city in Mongolia), Zonhala and Darhan (emerging industrial cities), Erdenet (the center of copper and molybdenum industries), and Suhbaatar (a frontier port between Mongolia and Russia).

The study area encompassed land within an empirical distance of $200 \mathrm{~km}$ on both sides of the Railway, as shown in Figure 1. The area covered 13 provinces, including Suhbaatar, Dornogovi, Dundgovi, Govisumber, Hentiy, Tov, Ulaanbaatar, Orhon, Bulgan, Arhangay, Selenge, Darhan, and Hovsgol. The land is predominantly high-lying and dominated by a temperate continental climate. Spring and autumn are short, and there is minimal precipitation. The southern part of the study area was covered by desert steppe, semi-desert land, and desert land [22], and the northern part was covered mainly by real steppe and forest [23]. The area was densely-populated and dominated economically by animal husbandry and mining industries.

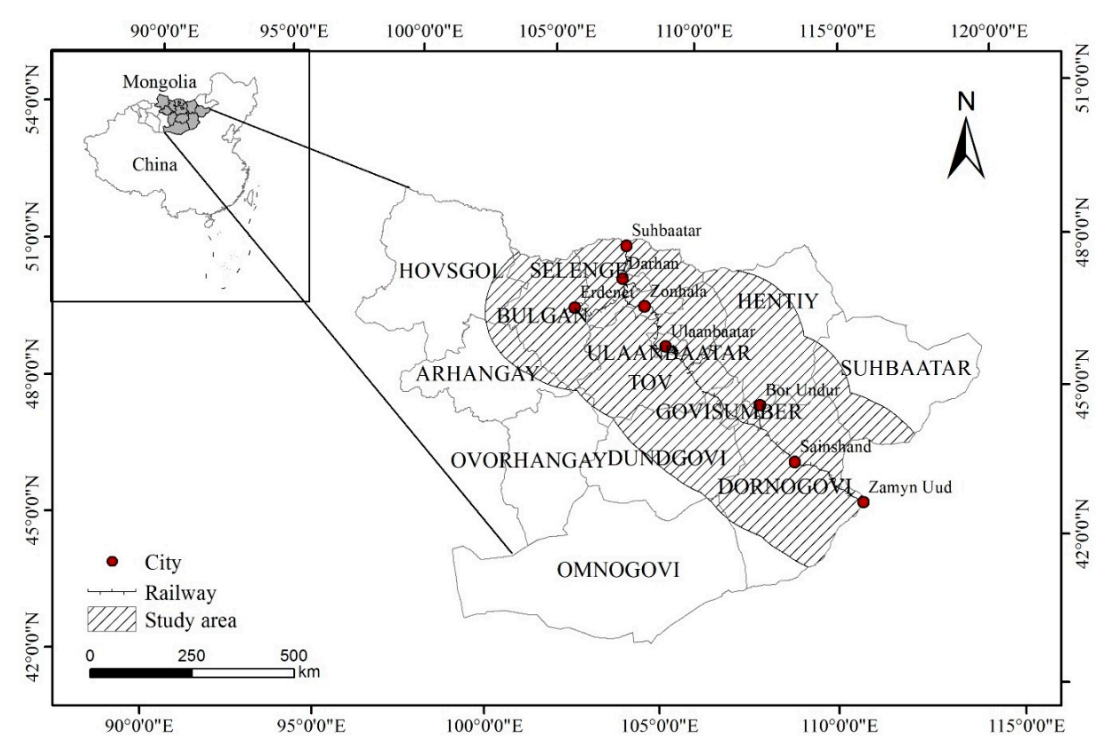

Figure 1. Regions along China-Mongolia railway (Mongolian section). 


\subsection{Data Sources}

In this study, 62 Landsat TM remote sensing images for 1990 and 2010 and 31 Landsat OLI remote sensing images for 2015 were acquired. The imaging data were taken between June and September during three different years. Most images have shorter imaging time intervals with a spatial resolution of $30 \mathrm{~m}$, and cloud coverage of less than $5 \%$. The main bands in these images are blue, green, red, near infrared (NIR), short-wave infrared 1 (SWIR1), short-wave infrared 2 (SWIR2), and middle infrared (MIR). Landsat TM and OLI images were obtained from the USGS website (source: United States Geological Survey, http://earthexplorer.usgs.gov/).

The auxiliary data used include the following: (1) Digital elevation model (DEM) and slope data with spatial resolution of $30 \mathrm{~m}$ (source: Thematic Database for Human-Earth System, Chinese Academy of Sciences, http://www.data.ac.cn); (2) average annual temperature, average annual precipitation, population, and livestock statistics (source: Mongolia's statistical information service website, http: //www.1212.mn [24]); (3) vector data of buffer zones within distances of $200 \mathrm{~km}, 100 \mathrm{~km}, 50 \mathrm{~km}, 30 \mathrm{~km}$, $10 \mathrm{~km}$, and $5 \mathrm{~km}$ on both sides of the Railway (source: Human-earth thematic database of Chinese Academy of Sciences, http://www.data.ac.cn), and field investigations data of land cover types in Mongolia acquired by a research team in 2013.

\subsection{Methods}

\subsubsection{Pre-Processing}

The remote sensing images were already georeferenced before we acquired them, and the coordinate system was the world geodetic system (WGS-1984). A number of steps were involved in the pre-processing starting with radiometric correction and atmospheric correction in this study. The radiometric calibration module in ENVI 5.1 (The Environment for Visualizing Images) was used to achieve radiation correction. Atmospheric correction was completed using the FLASSH module in ENVI 5.1. Prior to atmospheric correction, the sensor type, ground elevation, image generation time, atmospheric model parameters, and result of radiation correction should be added successively in this module. Finally, using the vector data from the Mongolian administrative division and buffer zones, the remote sensing images were clipped and mosaicked to synthesize the image map covering the entire study area.

\subsubsection{Remote-Sensing Interpretation of Land Cover Data}

We obtained refined land cover data in the study area through an object-oriented remote-sensing interpretation method. First, the eCognition software was used for multiresolution segmentation and spectral difference segmentation of each image in differing years. We selected different parameters for the experiments, and recorded the segmentation results and time consumption under different parameter conditions. Finally, we discovered a set of parameters with relatively fine segmentation effect and relatively short time consumption (scale parameter of multiresolution segmentation: 30; homogenization of shape: 0.1 ; homogenization of compactness: 0.5 ; and maximum spectral difference of spectral difference segmentation: (4). Based on the above operations, the images were segmented into homogeneous polygons (namely objects) of varying sizes according to the spectral heterogeneity between pixels $[25,26]$. The objects were then classified according to specified rules [27-29], taking full advantage of the textural, spatial, and spectral characteristics of ground objects.

By employing the remote-sensing classification system of $30 \mathrm{~m}$ resolution for Mongolia land cover developed by Wang et al. [30], we extracted information about land cover (forest, meadow steppe, real steppe, desert steppe, cropland, building areas, water, barren, sand, and desert) in regions along the Railway in Mongolia. The classification route in this paper is shown in Figure 2. 


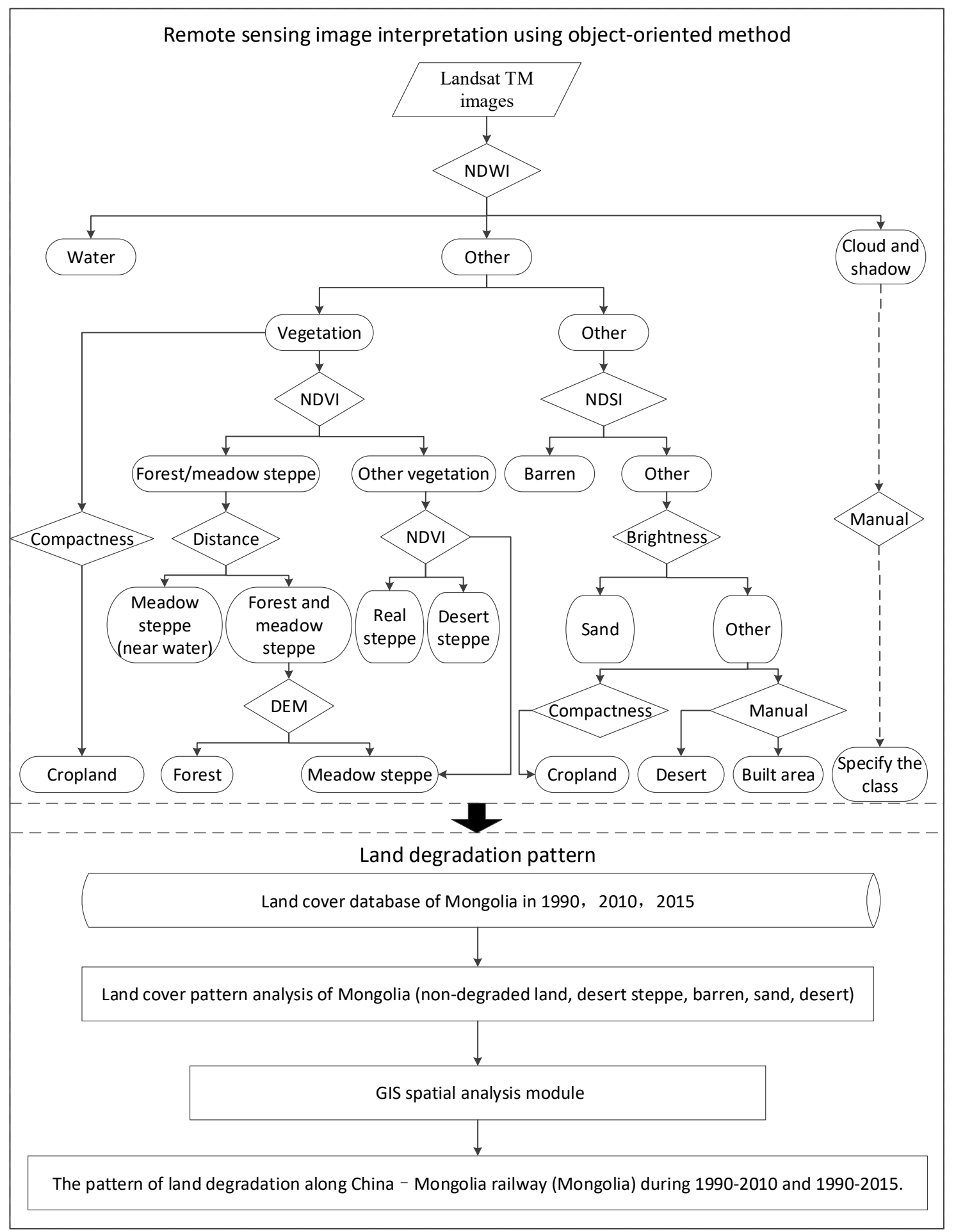

Figure 2. The technology flowchart.

The NDVI, normalized difference water index (NDWI), and normalized difference soil index (NDSI) were calculated using the following equations:

$$
\begin{gathered}
\text { NDVI }=(\mathrm{NIR}-\mathrm{R}) /(\mathrm{NIR}+\mathrm{R}), \\
\mathrm{NDWI}=(\mathrm{G}-\mathrm{NIR}) /(\mathrm{G}+\mathrm{NIR}), \\
\mathrm{NDSI}=(\mathrm{MIR}-\mathrm{NIR}) /(\mathrm{MIR}+\mathrm{N} I \mathrm{R}),
\end{gathered}
$$


where $\mathrm{R}(\mathrm{TM}=\mathrm{B} 3, \mathrm{OLI}=\mathrm{B} 4)$ and $\mathrm{NIR}(\mathrm{TM}=\mathrm{B} 4, \mathrm{OLI}=\mathrm{B} 5)$ denote the reflectivity of red and near infrared bands, respectively; $\mathrm{G}(\mathrm{TM}=\mathrm{B} 2, \mathrm{OLI}=\mathrm{B} 3)$ and $\mathrm{MIR}(\mathrm{TM}=\mathrm{B} 5, \mathrm{OLI}=\mathrm{B} 6)$ denote the reflectivity of green and NIR bands, respectively.

Table 1 showed the interpretation rules and reference threshold. NDWI was used for distinguishing water, cloud, shadow, and other land types. We classified objects that had NDWI $\leq 0$ as cloud and shadow. Then, we manually modified the actual land cover types under the cloud and shadow in combination with Google earth. Water reflectivity increases from the NIR band to the visible light band. The NDWI threshold was additionally used for distinguishing water and vegetation [31]. We classified objects that had NDWI $>0.036$ as water. NDVI is an index commonly used to extract vegetation information [32]. We classified objects that had NDVI $>0.1$ as vegetation. Other objects with NDVI $\geq 0.1$ were classified as non-vegetation areas. Due to dense vegetation and high NDVI value, forest and meadow steppe are often mixed together. We classified objects that had NDVI $>0.5$ as forest. However, we found that part of the meadow steppe was also misclassified as forest. Because the meadow steppe is often close to water, we divided the forest within 40 pixels from the water into meadow steppe. Since the forest is dense and high, we also confirmed the forest type by using DEM. We classified objects that had DEM > 1800 as forest. The vegetation coverage of meadow steppe and real steppe was sparse compared to that of forest, and the NDVI value was relatively low. We classified objects that had $0.4 \leq \mathrm{NDVI}<0.5$ and $0.2 \leq \mathrm{NDVI}<0.4$ as meadow steppe and real steppe, respectively. As the NDVI value was relatively small, and vegetation coverage was in the range of $5 \%$ to $10 \%$ in desert steppe, we classified objects that had $0.1<\mathrm{NDVI}<0.2$ as desert steppe. The vegetation coverage for barren and sand was below $5 \%$. Sand is characterized by a contiguous distribution, extremely low vegetation coverage, and high reflectivity. According to this feature, we chose NDSI to distinguish between sand and barren. We classified objects that had NDSI $>0.03$ as barren. We also classified objects that had brightness $\geq 600$ as sand. Cropland is easy to identify through its regular shape and can be accurately identified by the compactness of the parameters [33]. We classified objects that had compactness $\leq 1.4$ as cropland. The built area and desert were identified mainly through visual interpretation combined with human-computer interactive modification.

Table 1. Interpretation rules and reference threshold.

\begin{tabular}{cc}
\hline Land Cover Types & Rules and Reference Threshold \\
\hline Forest & NDVI $>0.5 ;$ DEM $>1800$ \\
Meadow steppe & $0.4 \leq$ NDVI $<0.5 ;$ Distance to water $<40$; DEM $\leq 1800$ \\
Real steppe & $0.2 \leq$ NDVI $<0.4$ \\
Desert steppe & $0.1 \leq$ NDVI $<0.2$ \\
Barren & NDSI $>0.03$ \\
Desert & Visual interpretation \\
Sand & Brightness $\geq 600$ \\
Cropland & Compactness $\leq 1.4$ \\
Built area & Visual interpretation \\
Water & NDWI $>0.036$ \\
\hline
\end{tabular}

\subsubsection{Land Degradation Information and Processing}

Land degradation refers to the decline in, or loss of, biological or economic productivity and diversity in any of the following: Rain-fed land (dry farmland), irrigated land, grassland, pasture land, forest, and woodland in arid, semiarid, dry, and semi-humid regions. This degradation occurs during land utilization, or under the action of one or multiple agents [34]. The land degradation process can be reflected through the land cover change. Based on the land cover data sets, we defined forest, meadow steppe, and real steppe as the non-degraded land. Desert steppe, barren, sand, and desert land cover types are defined as degraded land when they are moved in from non-degraded land.

Combined with previous studies, it is found that people mostly choose the regions within the range of $2 \mathrm{~km}, 5 \mathrm{~km}, 10 \mathrm{~km}, 30 \mathrm{~km}, 50 \mathrm{~km}$, and $100 \mathrm{~km}$ on both sides of the railway as the study area [35,36]. 
After comprehensive consideration of the natural landscape and the distribution characteristics of land cover types along the railway, the influence of the railway on the surrounding regional economy and human activities, we designated buffer zones on both sides of the Railway within distances of $5 \mathrm{~km}, 10 \mathrm{~km}, 30 \mathrm{~km}, 50 \mathrm{~km}, 100 \mathrm{~km}$, and $200 \mathrm{~km}$, respectively. Land degradation is a long process and will not change significantly in just a few years. To discover more obvious land degradation results, land degradation monitoring was carried out in intervals of 20 and 25 years. With technical support from a GIS spatial analysis module, we superposed land cover data, and generated map variations in land cover for regions along the Railway during 1990-2010 and 1990-2015, as shown in Figure 2. In this study, a spatial overlay analysis was used to superpose the land cover data of 1990 with the land cover data of 2010 and 2015 to analyze the changes. The areas of changed land cover types with land degradation were then extracted, and the distribution maps of newly-increased land degradation along the railway from 1990 to 2010 and from 1990 to 2015 were obtained. In turn, we identified the 25-year land degradation development trend and analyzed the driving forces behind the land degradation process.

\section{Results}

\subsection{Spatial Distribution Pattern of Different Land Cover Types}

Land cover data along the Railway were produced using an object-oriented method. The data sources for this verification of accuracy were composed of three main parts: The field verification points in 2013 (50 points), the intersecting longitude and latitude verification points downloaded from the Degree Confluence Program (119 points), and high-resolution sample points obtained from Google (140 points). A total of 309 verification points were collected. In 2013, we conducted a field investigation in Mongolia, during which we evenly arranged 50 field verification points using GPS instruments, and manually interpreted the local land cover types based on our prior knowledge and land cover interpretation criteria. The error evaluation results showed that the overall classification accuracy of the land cover product was $82.26 \%$ for $1990,92.34 \%$ for 2010 , and $92.75 \%$ for 2015 . Table 2 shows the user and producer accuracies of different land cover types in 1990 and 2010. Compared with the classification results obtained by Wei et al. and Tian et al. [22,37], this remote-sensing interpretation data set is considered more refined and accurate. The land cover data of Mongolia obtained in this study with a resolution of $30 \mathrm{~m}$, has much higher resolution than the results of Wei et al. at $1 \mathrm{~km}$ resolution. The overall classification accuracy of the results obtained by Tian et al. is $72.66 \%$, which is lower than the accuracy obtained in this study as well.

Table 2. Accuracy of land cover classification (UA: user accuracy; PA: producer accuracy).

\begin{tabular}{ccccccccccc}
\hline Years & $\begin{array}{c}\text { Types of } \\
\text { Accuracy }\end{array}$ & Forest & $\begin{array}{c}\text { Meadow } \\
\text { Steppe }\end{array}$ & $\begin{array}{c}\text { Real } \\
\text { Steppe }\end{array}$ & $\begin{array}{c}\text { Desert } \\
\text { Steppe }\end{array}$ & Barren & Sand & Cropland & $\begin{array}{c}\text { Built } \\
\text { Area }\end{array}$ & Water \\
\hline \multirow{2}{*}{1990} & UA (\%) & 61.29 & 40.00 & 64.41 & 45.95 & 83.56 & 12.50 & 100 & 83.33 & 90.91 \\
& PA (\%) & 82.61 & 33.33 & 56.72 & 41.46 & 79.22 & 100 & 100 & 100 & 95.23 \\
\hline \multirow{2}{*}{2010} & UA (\%) & 66.67 & 100 & 80.00 & 62.16 & 91.78 & 12.50 & 100 & 85.71 & 95.45 \\
& PA (\%) & 94.12 & 73.33 & 75.00 & 62.16 & 82.72 & 100 & 100 & 100 & 100 \\
\hline
\end{tabular}

Table 3 shows the area statistics of different land cover types along the Railway, and Figure 3 shows the spatial distribution characteristics of land cover along the Railway. 

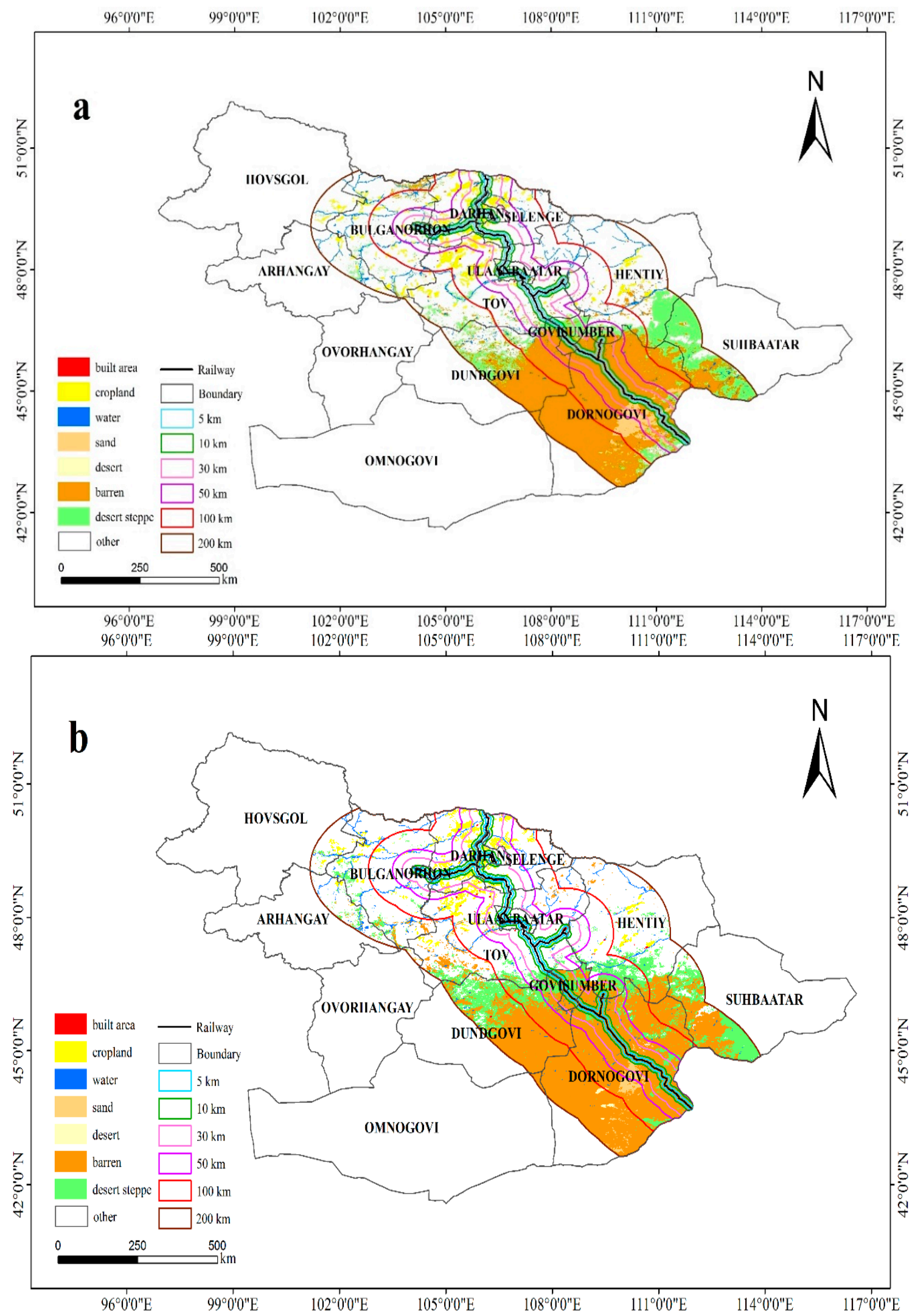

Figure 3. Cont. 


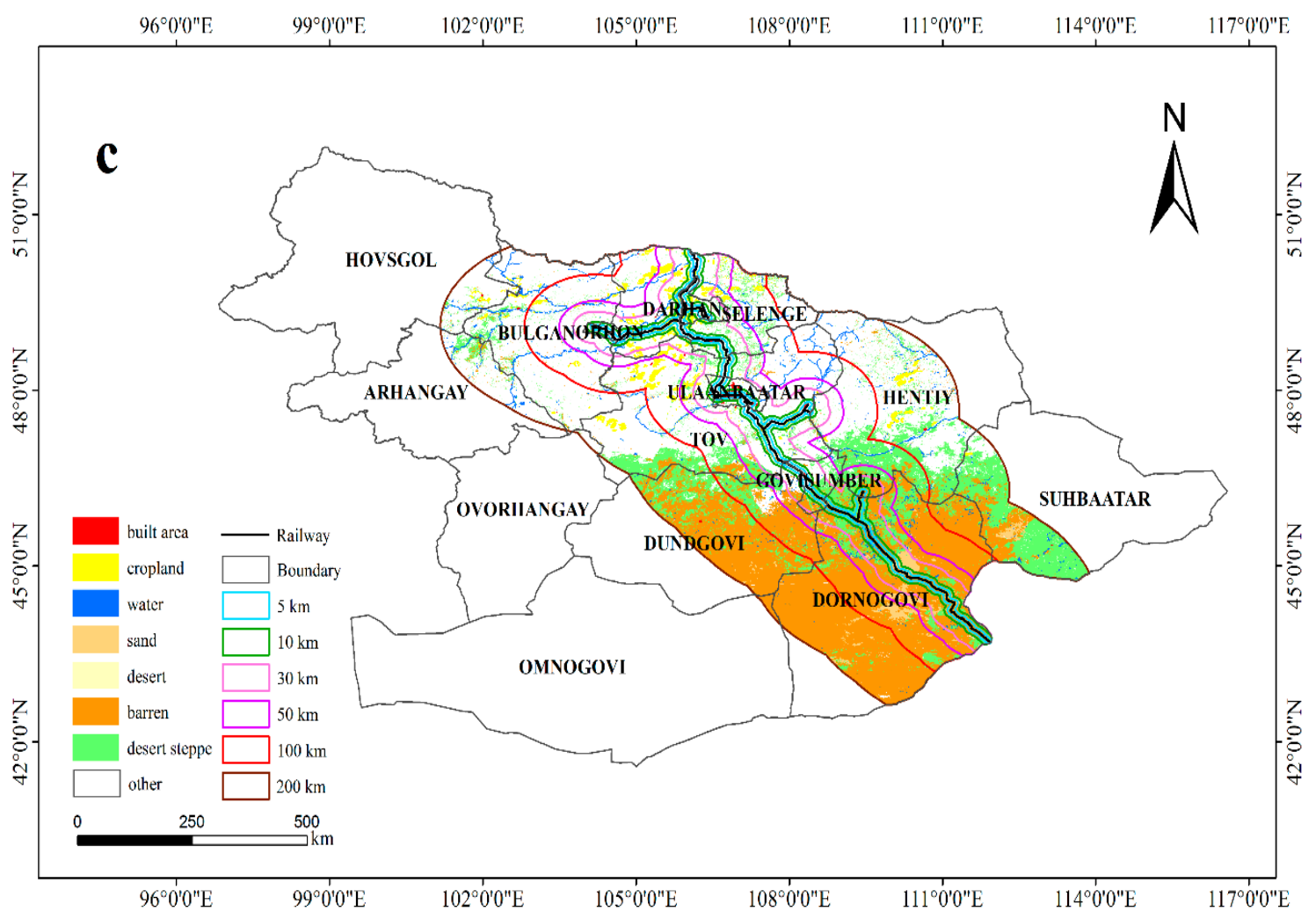

Figure 3. Land cover distribution map along the Railway. (a) 1990, (b) 2010, and (c) 2015.

Table 3. Areas of different land cover types over different distances on both sides of the Railway.

\begin{tabular}{|c|c|c|c|c|c|c|c|}
\hline Time & Land Cover Types & $200 \mathrm{~km}\left(\mathrm{~km}^{2}\right)$ & $100 \mathrm{~km}\left(\mathrm{~km}^{2}\right)$ & $50 \mathrm{~km}\left(\mathrm{~km}^{2}\right)$ & $30 \mathrm{~km}\left(\mathrm{~km}^{2}\right)$ & $10 \mathrm{~km}\left(\mathrm{~km}^{2}\right)$ & $5 \mathrm{~km}\left(\mathrm{~km}^{2}\right)$ \\
\hline \multirow{5}{*}{1990} & Desert steppe & $45,855.20$ & $13,531.30$ & 8157.00 & $24,487.40$ & 9265.70 & 717.00 \\
\hline & Barren & 118,590 & $64,532.30$ & $36,416.90$ & 4352.27 & 1327.07 & 4699.20 \\
\hline & Sand & 1247.11 & 5455.29 & 3058.11 & 1793.78 & 686.88 & 361.08 \\
\hline & Desert & 150.07 & 23.84 & 3.93 & 0.13 & 0 & 0 \\
\hline & Total & $165,842.40$ & $83,542.73$ & $47,635.94$ & $30,633.58$ & $11,279.65$ & 5777.28 \\
\hline \multirow{5}{*}{2010} & Desert steppe & $47,449.60$ & $20,590.70$ & 9353.56 & 4917.26 & 1463.50 & 722.09 \\
\hline & Barren & 133,268 & $68,185.90$ & $38,430.90$ & $25,824.70$ & 9909.92 & 5095.28 \\
\hline & Sand & 1899.03 & 1689.09 & 908.22 & 413.41 & 57.21 & 20.88 \\
\hline & Desert & 420.04 & 45.27 & 4.02 & 0 & 0 & 0 \\
\hline & Total & $183,036.7$ & $90,510.96$ & $48,696.70$ & $31,155.37$ & $11,430.63$ & 5838.25 \\
\hline \multirow{5}{*}{2015} & Desert steppe & $72,276.10$ & $34,531.02$ & $18,465.64$ & $11,148.44$ & 3704.39 & 1933.07 \\
\hline & Barren & $121,986.83$ & $59,275.09$ & $29,474.26$ & $18,027.28$ & 6899.97 & 3551.21 \\
\hline & Sand & 3072.35 & 2719.50 & 1936.20 & 1377.10 & 510.96 & 265.09 \\
\hline & Desert & 299.40 & 56.46 & 26.82 & 25.78 & 6.26 & 2.20 \\
\hline & Total & $197,634.68$ & $96,582.07$ & $49,902.92$ & $30,578.60$ & $11,121.58$ & 5751.57 \\
\hline
\end{tabular}

Figure 3a shows the land cover distribution along the Railway in 1990. Within a distance of $200 \mathrm{~km}$ on both sides of the Railway, the desert steppe is distributed mainly in scattered blocks in the northern part of Dundgovi, the northern and central parts of Govisumber, the western and southwestern parts of Suhbaatar, and the southeastern part of Dornogovi. Barren is distributed mainly in a big block area in southern Govisumber, eastern Dundgovi, Dornogovi, and the southwestern corner of Suhbaatar. Sand and desert are distributed mainly in the southeastern part of Dornogovi. Within distances of $200 \mathrm{~km}, 100 \mathrm{~km}$, and $50 \mathrm{~km}$ on both sides of the Railway, barren represents the highest proportion of the total area along the Railway $(28.50 \%, 28.87 \%$, and $29.90 \%$, respectively), followed by desert steppe $(11.02 \%, 6.05 \%$, and $29.90 \%$, respectively). Within distances of $30 \mathrm{~km}, 10 \mathrm{~km}$, and $5 \mathrm{~km}$ on both sides of the Railway, desert steppe represents the highest proportion of the total area $(31.78 \%, 33.12 \%$, and $5.01 \%$, respectively), followed by barren (5.65\%, $4.74 \%$, and $32.80 \%$, respectively). 
Figure $3 \mathrm{~b}$ shows the land cover distribution along the Railway in 2010. The land cover distribution characteristics in 2010 were very similar to those in 1990. Desert steppe was mainly distributed in fragmented areas in the northern part of Dundgovi, the middle part of Govisumber, the southern part of Hentiy, the southwestern part of Suhbaatar, and the sporadic regions within western Bulgan. Barren was mainly distributed in a big block area in the eastern part of Dundgovi, the northern and southern parts of Govisumber, Dornogovi, and the western part of Suhbaatar. Sand and desert are mainly distributed in central Dornogovi. Within distances of $200 \mathrm{~km}, 100 \mathrm{~km}, 50 \mathrm{~km}, 30 \mathrm{~km}, 10 \mathrm{~km}$, and $5 \mathrm{~km}$ on both sides of the Railway, barren represented the highest proportion of the total area $(32.02 \%, 30.51 \%, 31.55 \%, 33.52 \%, 35.42 \%$, and $35.57 \%$, respectively), followed by desert steppe $(11.40 \%$, $9.21 \%, 7.68 \%, 6.38 \%, 5.23 \%$, and $5.04 \%$, respectively).

Figure 3c shows the land cover distribution in 2015, within a distance of $200 \mathrm{~km}$ on both sides of the Railway. Desert steppe was mainly distributed in the western and southwestern parts of Suhbaatar, the southern part of Hentiy, the eastern part of Govisumber, the borders between southern Tov and northern Dundgovi, and in sporadic regions within western Bulgan. Barren was mainly distributed in large broken blocks in the southern and eastern parts of Dundgovi, the most of Dornogovi, the southwestern part of Suhbaatar. Sand and desert were concentratively distributed in central Dornogovi and southwestern Suhbaatar. Within distances of $200 \mathrm{~km}, 100 \mathrm{~km}, 50 \mathrm{~km}, 30 \mathrm{~km}, 10 \mathrm{~km}$, and $5 \mathrm{~km}$ on both sides of the Railway, barren represented the highest proportion of all land types $(29.31 \%, 26.52 \%, 24.20 \%, 23.40 \%, 24.66 \%$, and $24.79 \%$, respectively), followed by desert steppe $(17.37 \%$, $15.45 \%, 15.16 \%, 14.47 \%, 13.24 \%$, and $13.49 \%$, respectively).

\subsection{Spatial Distribution Pattern of Land Degradation}

Figure 4 and Table 4 shows the distribution, areas and proportions of the newly-increased land degradation regions along the Railway. From Figure 4a, it is evident that land degradation areas were mainly distributed in blocks in the southeastern, middle, and northwestern parts of the region along the Railway. Land degradation areas covered $43,970.60 \mathrm{~km}^{2}$, accounting for $10.57 \%$ of the total land area within a distance of $200 \mathrm{~km}$ on both sides of the Railway. There were three main types of land degradation, i.e., non-degraded land degraded into desert steppe, desert steppe degraded into barren, and non-degraded land degraded into barren. Of these degraded land types, non-degraded land degraded into desert steppe covered the largest area accounting for approximately $45.69 \%$ of the total degraded land area. It was mainly distributed in strips in the western border region of Bulgan, the southern border region of Tov, the northern border region of Dundgovi and the southern part of Hentiy. The desert steppe land shifted into barren covered the second largest area accounting for approximately $40.42 \%$ of total degraded land area. It was mainly distributed in the middle part of Dundgovi, the northern part of Govisumber, the southeastern part of Hentiy, the western part of Suhbaatar, the northeastern and southeastern parts of Dornogovi. Areas of non-degraded land shifted into barren account for approximately $12.06 \%$ of the total land degradation area. It was sporadically distributed in southeastern Dornogovi, northern Dundgovi, northern Tov, and northern Hentiy. However, an area of land approximately $23,164.56 \mathrm{~km}^{2}$ of land was restored to varying degrees in regions along the Railway and accounts for approximately $5.57 \%$ of the total land area. There were three main types of land restoration: Desert steppe to non-degraded land, restoration of barren to desert steppe, and restoration of barren to non-degraded land. 

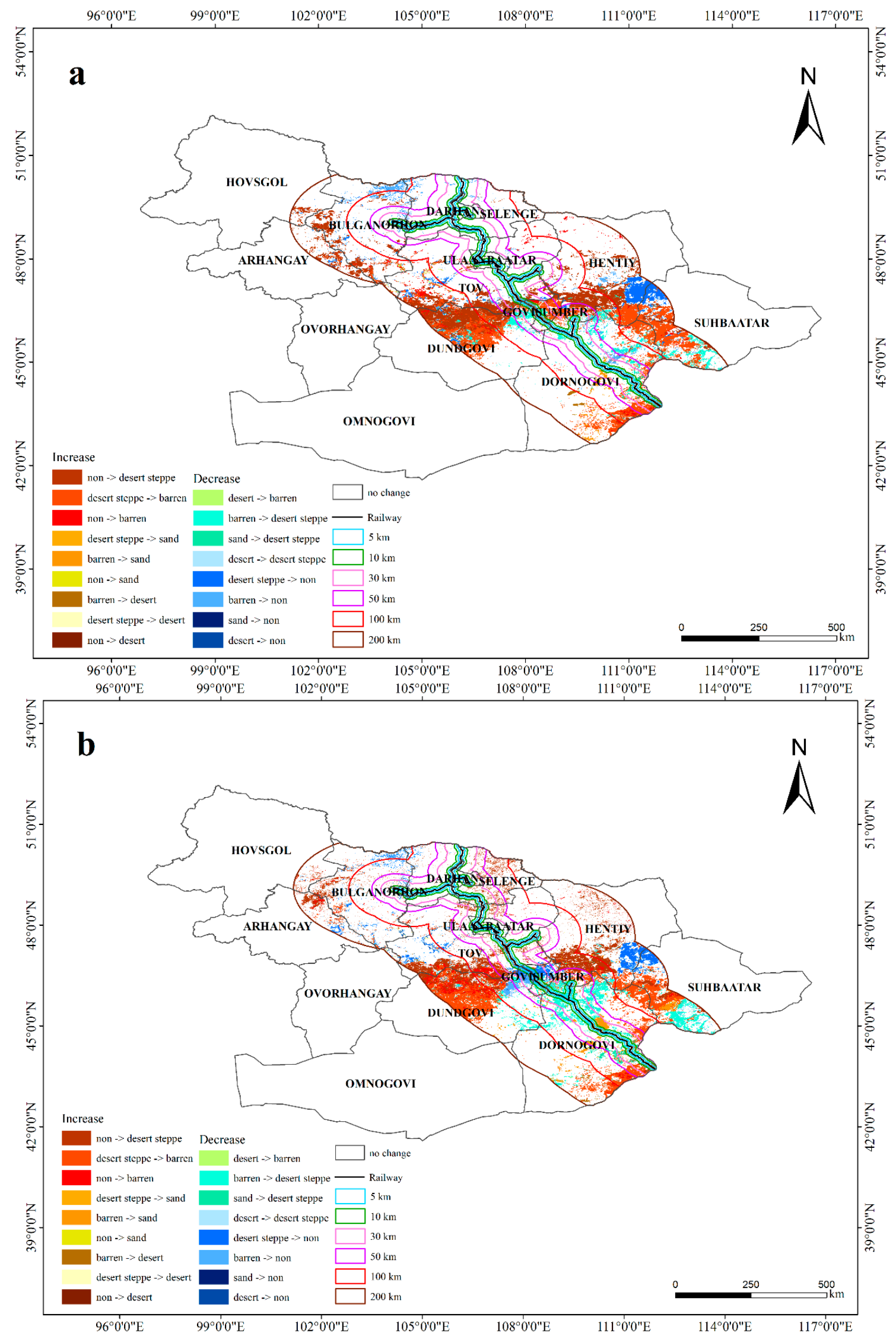

Figure 4. Cont. 


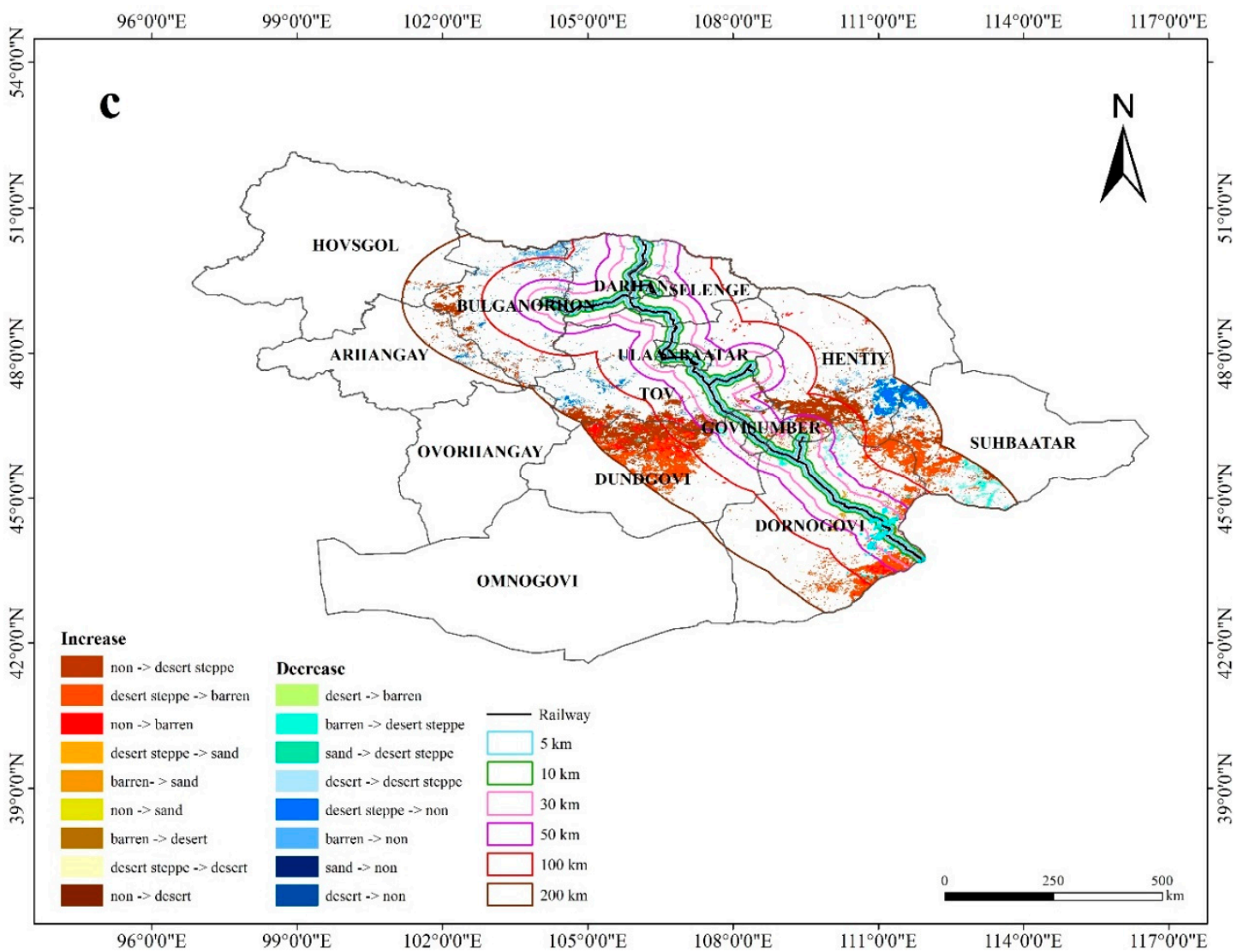

Figure 4. The regional distribution map of newly-increased land degradation along the Railway. (a) 1990-2010, (b) 1990-2015, and (c) the persistent change region in these two periods of 1990-2010 and 1990-2015.

Table 4. The area and proportion of newly-increased land degradation areas along the Railway.

\begin{tabular}{|c|c|c|c|c|c|c|}
\hline Time & Degradation & Area $\left(\mathrm{km}^{2}\right)$ & $\%$ & Restoration & Area $\left(\mathrm{km}^{2}\right)$ & $\%$ \\
\hline \multirow{10}{*}{ 1990-2010 } & Non $\rightarrow$ desert steppe & $20,091.10$ & 45.69 & Desert steppe $\rightarrow$ non & $11,010.90$ & 47.53 \\
\hline & Non $\rightarrow$ barren & 5304.79 & 12.06 & Barren $\rightarrow$ non & 1745.03 & 7.53 \\
\hline & Non $\rightarrow$ sand & 0.06 & 0.0001 & Barren $\rightarrow$ desert steppe & $10,232.80$ & 44.17 \\
\hline & Non $\rightarrow$ desert & 18.62 & 0.04 & Sand $\rightarrow$ desert steppe & 105.51 & 0.46 \\
\hline & Desert steppe $\rightarrow$ barren & $17,771.30$ & 40.42 & Sand $\rightarrow$ non & 4.29 & 0.02 \\
\hline & Desert steppe $\rightarrow$ desert & 49.28 & 0.11 & Desert $\rightarrow$ barren & 54.48 & 0.24 \\
\hline & Desert steppe $\rightarrow$ sand & 7.85 & 0.02 & Desert $\rightarrow$ desert steppe & 4.28 & 0.02 \\
\hline & Barren $\rightarrow$ sand & 474.25 & 1.08 & Desert $\rightarrow$ non & 7.27 & 0.03 \\
\hline & Barren $\rightarrow$ desert & 253.35 & 0.58 & & & \\
\hline & Total & $43,970.60$ & 1 & Total & $23,164.56$ & 1 \\
\hline \multirow{10}{*}{ 1990-2015 } & Non $\rightarrow$ desert steppe & $32,574.35$ & 55.84 & Desert steppe $\rightarrow$ non & $11,330.70$ & 33.26 \\
\hline & Non $\rightarrow$ barren & 9541.76 & 16.36 & Barren $\rightarrow$ non & 3586.15 & 10.53 \\
\hline & Non $\rightarrow$ sand & 15.37 & 0.03 & Barren $\rightarrow$ desert steppe & $18,710.99$ & 54.92 \\
\hline & Non $\rightarrow$ desert & 10.80 & 0.02 & Sand $\rightarrow$ desert steppe & 355.93 & 1.04 \\
\hline & Desert steppe $\rightarrow$ barren & $13,862.02$ & 23.76 & Sand $\rightarrow$ non & 4.62 & 0.01 \\
\hline & Desert steppe $\rightarrow$ desert & 38.45 & 0.07 & Desert $\rightarrow$ barren & 12.62 & 0.04 \\
\hline & Desert steppe $\rightarrow$ sand & 66.12 & 0.11 & Desert $\rightarrow$ desert steppe & 16.12 & 0.05 \\
\hline & Barren $\rightarrow$ sand & 2105.81 & 3.61 & Desert $\rightarrow$ non & 52.25 & 0.15 \\
\hline & Barren $\rightarrow$ desert & 122.58 & 0.21 & & & \\
\hline & Total & $58,337.26$ & 1 & Total & $34,069.38$ & 1 \\
\hline
\end{tabular}

Figure $4 \mathrm{~b}$ shows the distribution of the newly-increased land degradation in regions along the Railway during 1990-2015. It is evident that land degradation areas were mainly distributed in blocks in the southeastern and middle parts, and in sporadic spots in the northwestern, northern, and eastern parts of the area along the Railway. Land degradation areas covered $58,337.26 \mathrm{~km}^{2}$, which represent 
$14.02 \%$ of the total land area within a distance of $200 \mathrm{~km}$ of both sides of the Railway. Of these degraded land types, the largest area was represented by non-degraded land changed into desert steppe, representing approximately $55.84 \%$ of the total degraded land area. It was mainly distributed in the southern part of Hentiy, the southern borders of Tov, sporadic regions of northern Tov, and in the western borders of Bulgan. The second largest area was desert steppe degraded into barren, representing approximately $23.76 \%$ of the total degraded land area. It was mainly distributed in the southeastern and northeastern parts of Dornogovi, the western part of Suhbaatar, and the middle part of Dundgovi. Areas of non-degraded land changed into barren account for approximately $16.36 \%$ of the total area, which were sporadically distributed in southern Hentiy, northern Dundgovi, and on the southern borders of Tov. Approximately $34,069.38 \mathrm{~km}^{2}$ land was restored to a varying degree, accounting for approximately $8.19 \%$ of the total land area.

Figure 4c shows the persistent change region along the Railway in the two periods of 1990-2010 and 1990-2015. Table 5 shows the area and proportion of the same and persistent change region in these two periods. It is evident that the areas of persistent land degradation were mainly distributed in the southeastern and middle parts, and in sporadic spots in the northwestern part of the area along the Railway. The areas of persistent land degradation covered $22,491.73 \mathrm{~km}^{2}$, which represented $5.41 \%$ of the total land area within a distance of $200 \mathrm{~km}$ on both sides of the Railway. Of these degraded land types, the largest area was represented by non-degraded land changed into desert steppe, representing approximately $47.17 \%$ of the total persistent degraded land area. It was mainly distributed in the southwestern part of Hentiy, the southern borders of Tov, and in the western borders of Bulgan. The second largest area was desert steppe degraded into barren, representing approximately $40.79 \%$ of the total persistent degraded land area. It was mainly distributed in the southeastern and northeastern parts of Dornogovi, the southwestern part of Suhbaatar, and the middle part of Dundgovi. Areas of non-degraded land changed into barren accounted for approximately $11.48 \%$ of the total area, which were sporadically distributed in the northern part of Dundgovi, and on the southern borders of Tov. Approximately $11,896.51 \mathrm{~km}^{2}$ land was persistently restored to a varying degree, accounting for approximately $2.86 \%$ of the total land area.

Table 5. The area and proportion of the same and persistent change region in the two periods of 1990-2010 and 1990-2015.

\begin{tabular}{cccccc}
\hline Degradation & Area $\mathbf{( k m}^{\mathbf{2}} \mathbf{)}$ & $\mathbf{\%}$ & Restoration & Area $\mathbf{( k m}^{\mathbf{2}} \mathbf{)}$ & $\mathbf{\%}$ \\
\hline Non $\rightarrow$ desert steppe & $10,609.40$ & 47.17 & Desert steppe $\rightarrow$ non & 7175.74 & 60.32 \\
Non $\rightarrow$ barren & 2582.98 & 11.48 & Barren $\rightarrow$ non & 670.53 & 5.64 \\
Non $\rightarrow$ sand & 0.03 & 0.00013 & Barren $\rightarrow$ desert steppe & 3990.89 & 33.55 \\
Non $\rightarrow$ desert & 0.59 & 0.00262 & Sand $\rightarrow$ desert steppe & 52.52 & 0.44 \\
Desert steppe $\rightarrow$ barren & 9175.01 & 40.79 & Sand $\rightarrow$ non & 0 & 0 \\
Desert steppe $\rightarrow$ desert & 14.10 & 0.06 & Desert $\rightarrow$ barren & 0.09 & 0.00075 \\
Desert steppe $\rightarrow$ sand & 1.23 & 0.00547 & Desert $\rightarrow$ desert steppe & 0.70 & 0.00588 \\
Barren $\rightarrow$ sand & 108.38 & 0.48 & Desert $\rightarrow$ non & 6.04 & 0.0508 \\
Barren $\rightarrow$ desert & 0.009 & 0.00004 & & & 11896.51 \\
Total & $22,491.73$ & 1 & Total & 1 \\
\hline
\end{tabular}

\section{Discussion}

\subsection{Spatiotemporal Distribution Characteristics of Land Cover and Newly-Increased Land Degradation Along the Railway}

According to the spatial distribution pattern of different land types in regions along the Railway in 1990, 2010, and 2015, sand and desert were concentratively distributed in the middle part Dornogovi, barren was concentratively distributed in southern regions, and desert steppe was concentratively distributed in central and southeastern regions. This reflects obvious transitional characteristics along the Railway. During 1990-2015, the total area of desert steppe, barren, sand and desert had been increasing. The overall distribution of the newly-increased degraded land demonstrated an obvious 
zonality, and was mainly distributed in the middle region along the Railway. Due to the influence of natural and human factors, there was less newly-increased land degradation area in the south. The land cover type in this area was dominated by barren, for example, and the Gobi was widely distributed here. In addition, previous land degradation monitoring results showed that most of southern Mongolian regions (including Dundgovi, Dornogovi, and Omnogovi) had been mostly covered by severe desertification and extremely severe desertification land for a long period. In other words, the land in southern regions was unlikely to be further degraded within the short term. In this study area, the distribution of the newly-increased land degradation areas presented transitional characteristics. The land degradation degree gradually increased from north to south, and the land degradation from non-degraded land to desert steppe was the most dominant type observed.

Although continuing land degradation was occurring, some areas in regions along the Railway were being restored. The areas of persistent restored land were mainly distributed in the southeastern part of Hentiy, the southwestern part of Suhbaatar, and the northeastern parts of Bulgan. Land was mainly being restored from desert steppe to non-degraded land, which implies that desert steppe had a relatively high restorability capacity. Although there had been an increase in the amount of land being restored, and the ability to restore land had been improved, land restorability lags behind the land degradation process. Furthermore, the gap between the speed at which land is restored and that at which land degradation occurs continues to widen. The amount of degraded land also continues to expand toward northern provinces such as Tov, Hentiy, and Selenge. Overall, there has been an increased trend in land degradation along the Railway.

The results showed that the degree and speed of land degradation vary somewhat from region to region along the Railway. During 1990-2015, the middle regions were the most responsive areas to the land degradation process, and land degradation proceeded from non-degraded land to desert steppe. Desert steppe was characterized by a relatively low degree of land degradation, was unstable land, but had a high restorability potential. Therefore, to prevent further land degradation and suppress aggravation of desertification along the Railway, it is necessary to focus monitoring and prevention of land degradation on these newly-increased land degradation regions, which have a low degree of land degradation.

We found that the phenological state of vegetation can affect remote sensing classification and manual interpretation. In the interpretation of land cover, the transition zone between vegetation and non-vegetation or between steppe and barren is easily misclassified. The influence of the phenological state of vegetation on these transition areas is greater. In the future, strengthening the study on the phenological effects of vegetation may be the key to solve this problem and improve the classification accuracy in Mongolia. Moreover, although regions within $200 \mathrm{~km}$ along both sides of the Railway were selected as the study area, it remains to be verified whether the variation trends and laws relating to land degradation throughout Mongolia are consistent with the conclusions obtained in this study. To explore the distribution pattern, variation, and mechanisms involved in land degradation along the Railway in greater depth, this study will be extended in the future to cover the entire Mongolian territory, with the aim of discussing these issues in a broader context.

\subsection{Analysis of Driving Forces Behind Land Degradation in Regions Along the Railway}

\subsubsection{Natural Factors}

Mongolia is dominated by a temperate continental climate. The average temperature varies very significantly. According to a statistical analysis of meteorological data acquired from 12 meteorological stations along the Railway, air temperature showed a slow rising trend and significant fluctuation during 2000-2015 (as shown in Figure 5), and the difference between the maximum and minimum annual average temperature was $3.14^{\circ} \mathrm{C}$. The temperature fluctuations create an adverse effect on the normal growth and succession of vegetation, and can cause a reduction in vegetation coverage and productivity, severe grassland degradation, and can thereby accelerate the land degradation process. 


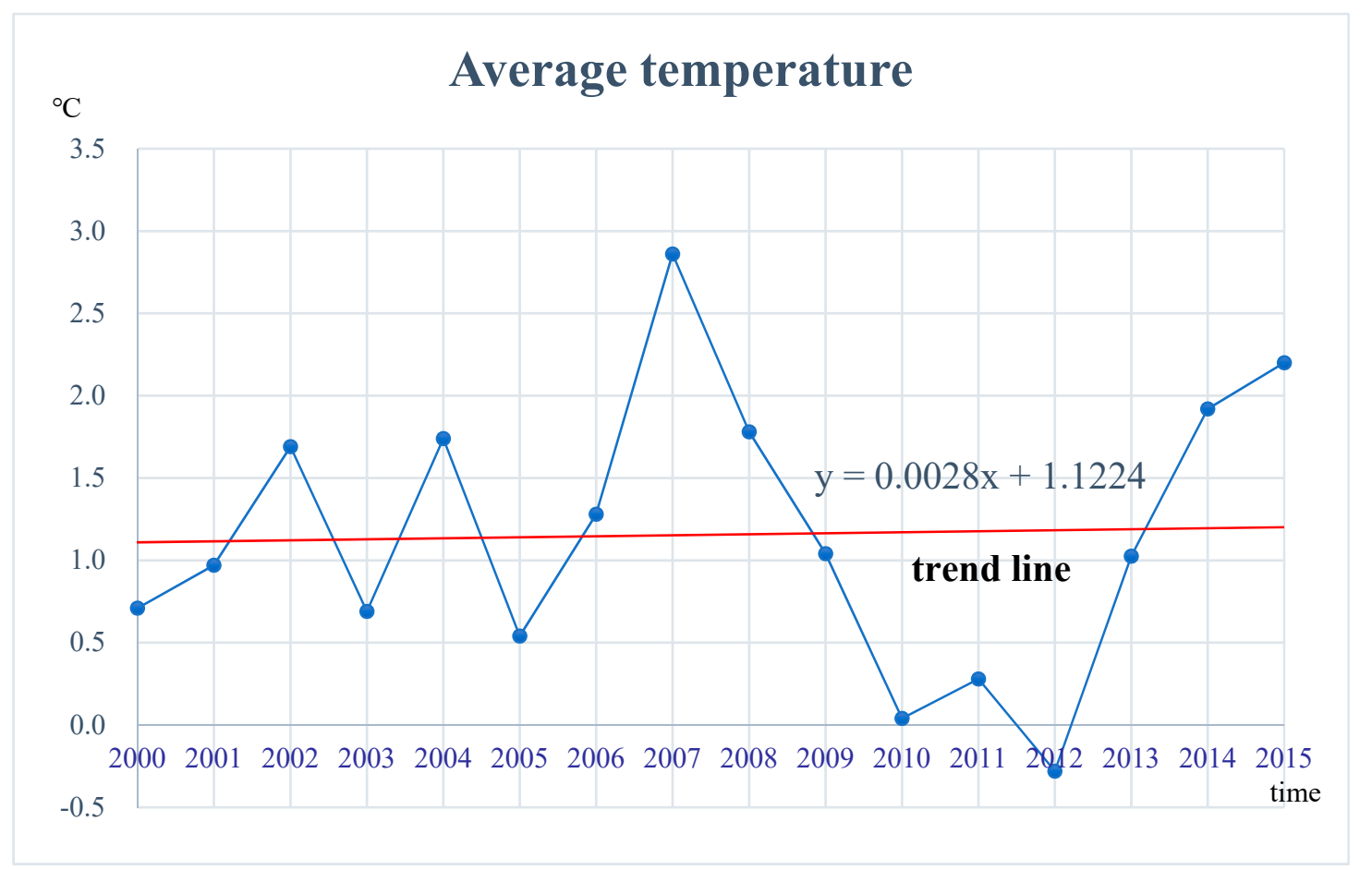

Figure 5. The annual average temperature along the Railway.

Mongolia falls within arid and semiarid regions, and the precipitation in the country has a significant influence on vegetation growth. There is a very low level of annual precipitation in Mongolia. We obtained the average annual precipitation data of 12 meteorological stations covered by the study area through the website of Mongolia Statistical Information Service. After calculating these data, we found that the average annual precipitation from 2000 to 2010 was $2494.20 \mathrm{~mm}$ and from 2011 to 2015 was $2361.42 \mathrm{~mm}$ [24], thereby declining overall. In addition, the precipitation distribution has obvious zonal characteristics in the Mongolian Plateau: It increases gradually from south to north [38]. Vegetation growth is suppressed with decreased precipitation along the Railway, where precipitation mainly occurs from June to September. There is minimal precipitation in spring and winter, which aggravates the spring and winter droughts and prevents vegetation growth, thus accelerating the land degradation process. However, frequent summer and autumn rainstorms also aggravate water and soil loss, erosion deposition, and surface crushing, which could accelerate the land degradation process and increases the risk of floods in the rainy season. In the early morning of 12 August 2018, the No. 286 passenger train running along the China-Mongolia railway (Ulaanbaatar-Sainshand section) derailed in Airag Soum of Dornogovi, overturning it and injuring passengers in the process [39]. Prior to this accident, Airag Soum had suffered an accumulated precipitation of $82 \mathrm{~mm}$ during incessant rains, and most of the rainwater remained within the surface soil. Flooding caused by the burst of heavy rainfall destroyed the railroad bed, which ultimately caused the accident.

\subsubsection{Socioeconomic Factors}

Overgrazing and population migration can accelerate the land degradation process in regions along the Railway. The animal husbandry and mining industries are Mongolia's two mainstay industries. As shown in Figure 6a, with the increased demand for cashmere at home and abroad during 2006-2015, there was an increase of 2,876,827 in the breeding quantity of goats in most provinces (Bulgan, Selenge, Orkhon, Darkhan, Tov, Ulaanbaatar, Hentiy, Govisumber, Dundgovi, and Dornogovi) of this study area (an increase of 73.66\%) [24]. Due to their great foraging capacity, goats chew grass roots when there is insufficient grass, which damages pastures and directly degrades the land. Mining enterprises in southwestern Mongolia have also encroached on pasture grounds, and herdsmen have 
been forced to migrate toward northeastern Mongolia across the Railway to find pastures. As a result, the population in eastern Mongolia has increased. Ulaanbaatar, Darhan and Tov are major political and economic centers of Mongolia, as well as important destinations or transit stations for the migration of herdsmen. During 2006-2015, the population of most provinces (Bulgan, Selenge, Orkhon, Darkhan, Tov, Ulaanbaatar, Hentiy, Govisumber, Dundgovi, and Dornogovi) in the study area increased by 417,208 , representing an increase of $25.50 \%$ (as shown in Figure $6 \mathrm{~b}$ ). After being displaced by mining areas, pasture grounds have migrated eastward and northward, which has also aggravated overgrazing in adjacent regions of the Railway [40].

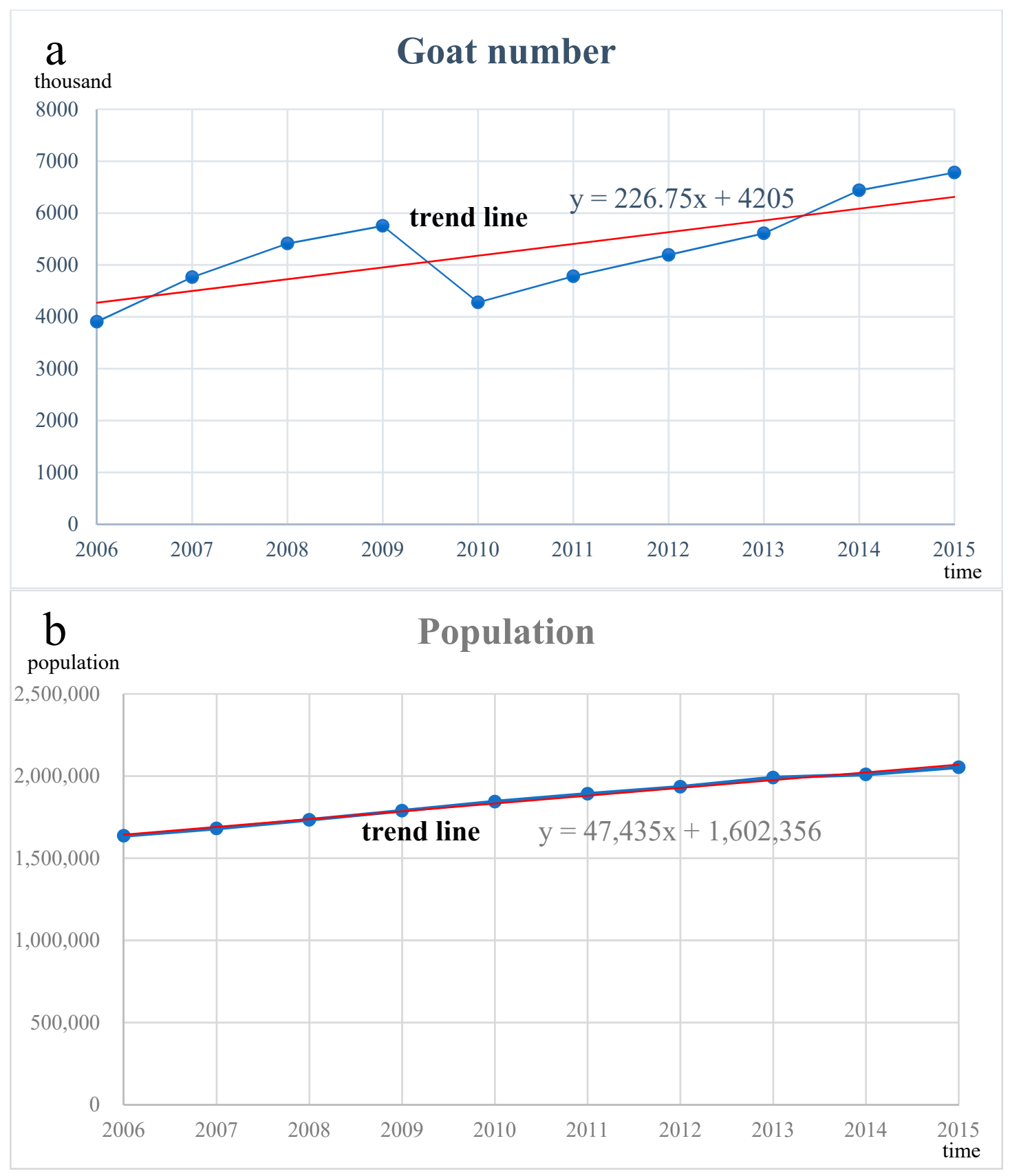

Figure 6. The annual population and the annual number of goats along the Railway. (a) goat number and (b) population.

To promote economic development, Mongolia has actively constructed railway and road infrastructure, which can accelerate land degradation. Along with this growing trend, there has 
been an increasing demand for engineering construction land. To reduce construction costs, many construction companies have acquired soil directly from adjacent infrastructure regions without undertaking reclamation measures. Consequently, the ground's surface is bare and severely crushed in these areas, which accelerates the land degradation process. Southern Mongolia has abundant mineral resources such as coal, fluorite, tungsten, gold, iron, and tin, and several strategic mineral bases [41]. With the development of the mining industry, mineral deposits have been abandoned and piled up together with mined soil, causing an intensified flow of sand dust, thus increasing the risk of land degradation [42]. Increased infrastructure construction for both transport and mining industries has deepened land disturbance in southern Mongolia, which has subsequently increased the degraded land area.

Rapid urbanization brings an increased risk of land degradation, and in response, Mongolia enacted a "civil freedom" policy in the 1990s with respect to citizens' residential location choices [7]. This policy stimulated the massive migration of herdsmen to resource-intensive regions, including the capital peripheral regions of important traffic arteries, regions near water resources (such as rivers, lakes, and wells), to central cities of provinces, and to Ulaanbaatar. This has drastically accelerated the urbanization process along the Railway. During 1990-2015, the urban population of regions adjacent to the Railway (including Selenge, Darhan, Orhon, Nov, Ulaanbaatar, Govisumber, and Dornogovi) increased by approximately 883,800 , an increase of approximately $108 \%$ [24]. In the absence of reasonable planning and administration, land available for urban construction has been underutilized, many land resources have been squandered, and the vegetation coverage of local regions has been reduced. All these factors have produced a higher risk of land degradation. As the area of land degradation expands and available land continues to decrease, the sustainable development potential in this area will also decrease.

\section{Conclusions}

Through remote-sensing interpretation, we acquired refined data for 1990, 2010, and 2015 with respect to different land cover types in regions along the Railway. We then analyzed the change of land cover types in 1990, 2010, and 2015 by using the GIS spatial analysis technology, and acquired land degradation patterns occurring over the 25 most recent years. Based on the analyses, we found that land cover types in this region have obvious transitional characteristics. In particular, barren, desert steppe, and non-degraded land cover types were distributed in a particular sequence from south to north. In the 25-year period, there had been obvious zonation of the newly-increased areas of degraded land in the region: They were mostly concentrated in the middle part and the degree of land degradation gradually worsened from north to south. Desert steppe, barren, sand, and desert in regions along the Railway were mainly distributed in the southern part but have tended to expand northward, showing a trend of land degradation expansion. However, some land has been gradually restored, but the restoration ability lags far behind the land degradation process. The joint effect of natural and socioeconomic factors has resulted in land degradation in such regions. Specifically, we speculate that land degradation along the Railway region is induced by significant temperature fluctuations and decreased rainfall and has been aggravated by population migration, overgrazing, infrastructure construction, unreasonable mineral exploitation, and rapid urbanization. This study suggests that monitoring and prevention of land degradation in the regions along the Railway should focus on the particular regions where slight land degradation is newly increasing. To promote the sustainable development of the China-Mongolia-Russia Economic Corridor regions, it is necessary to make reasonable plans related to human activities in these regions, to enhance their ability to tackle climate and environmental changes, and to prevent and control ecological risks. To further discover a more comprehensive and detailed process of land degradation in the regions along the Railway, we will conduct an encryption analysis at intervals of 5 years or 10 years, and strengthen the dynamic study of land degradation at different internal distances within the study area or throughout Mongolia. 
We will also analyze the land degradation process and development trend from a wider perspective throughout Mongolia in the future.

Author Contributions: J.W. was responsible for the research design, analysis, and designed and reviewed the manuscript. H.W. drafted the manuscript and was responsible for data preparation, experiments, and analyses. K.C., G.L. and L.B. participated in data collection and processing. A.O., S.C., D.D. and E.N. organized and participated in the field work of the study. All authors contributed to the editing and reviewing of the manuscript.

Funding: This research was funded by the Strategic Priority Research Program (Class A) of the Chinese Academy of Sciences grant number XDA19040501 and XDA20030203012, the fund program of the Asia Research Center, Mongolia and Korea Foundation for Advanced Studies grant number P2018-3606, and the Construction Project of the China Knowledge Center for Engineering Sciences and Technology grant number CKCEST-2018-2-8.

Acknowledgments: We are grateful to the members of the research team for the remote-sensing interpretation of Mongolian land cover, and to the National University of Mongolia and Geography \& Geo-ecology Institute at the Mongolian Academy of Sciences (who rendered full support to our field investigation and verification in Mongolia).

Conflicts of Interest: The authors declare no conflict of interest.

\section{References}

1. Ren, X.J. An analysis of the international geo-economic role of the Siberian railway-A promising international transport corridor. J. Rus. Stud. 2007, 1, 34-37.

2. The State Council of the People's Republic of China. The 5th Anniversary of Chinese President Jinping Xi's the 'Belt and Road Initiative': The Great Practice of Building a Community of Shared Future for Mankind. 2018. Available online: http://www.gov.cn/xinwen/2018-10/05/content_5327979.htm (accessed on 10 April 2019).

3. National Development and Reform Commission. The Outline of the Plan for Building the Economic Corridor Between China, Mongolia and Russia. 2016. Available online: http://www.ndrc.gov.cn/zcfb/zcfbghwb/ 201609/t20160912_818326.html (accessed on 16 October 2018).

4. The Belt and Road Portal. Mongolia: Steppe Road. 2016. Available online: https://www.yidaiyilu.gov.cn/ zchj/gijj/1066.htm (accessed on 10 April 2019).

5. United Nations Convention to Combat Desertification. LDN Country Profile-Mongolia. 2018. Available online: https://knowledge.unccd.int/sites/default/files/ldn_targets/2019-02/Mongolia_3.pdf (accessed on 10 April 2019).

6. Li, Y.W. Study on Risk Assessment of Desertification Disaster in Xilin Gol Grassland. Master's Thesis, Inner Mongolia Agricultural University, Huhehaote, China, 2018.

7. Buren, G.W. Research on Current Status, Causes and Prospect of Desertification in Mongolia. Master's Thesis, Inner Mongolia University, Huhehaote, China, 2011.

8. Bai, W.Y.; Jin, L. Comparative study on the ecological environment problems and their solutions between Mongolia and Inner Mongolia. J. Econ. Forum 2015, 5, $18-21$.

9. Liu, A.X.; Wang, C.Y.; Wang, J.; Shao, X.M. Method for remote sensing monitoring of desertification based on MODIS and NOAA/AVHRR data. J. Trans. CSAE 2007, 23, 145-150.

10. Unurbaatar, B.; Caoligeer, Y.H. The Spatial and Temporal Changes of Desertification in the Mongolian Plateau from 2000-2010. In Proceedings of the Risk Analysis and Crisis Response in Information Technology—China Disaster Prevention Association Risk Analysis Professional Committee Annual Meeting, China Disaster Prevention Association Risk Analysis Professional Committee, Beijing, China, 1-2 March 2014.

11. Zhuo, Y. The Ration Remote Sensing Method Study of Desertification of Mongolia Plateau Based on MODIS Data. Master's Thesis, Inner Mongolia Normal University, Huhehaote, China, 2007.

12. Pignatti, S.; Acito, N.; Amato, U.; Casa, R.; Castaldi, F.; Coluzzi, R.; De Bonis, R.; Diani, M.; Imbrenda, V.; Laneve, G.; et al. Environmental products overview of the Italian hyperspectral prisma mission: The SAP4PRISMA project. In Proceedings of the 2015 IEEE International Geoscience and Remote Sensing Symposium (IGARSS), Milano, Italy, 26-31 July 2015; pp. 3997-4000.

13. Mansour, K.; Mutanga, O.; Adam, E.; Abdel-Rahman, E.M. Multispectral remote sensing for mapping grassland degradation using the key indicators of grass species and edaphic factors. J. Geocarto Int. 2016, 31, 477-491. [CrossRef] 
14. Meusburger, K.; Bänninger, D.; Alewell, C. Estimating vegetation parameter for soil erosion assessment in an alpine catchment by means of Quick Bird imagery. J. Int. J. Appl. Earth Obs. Geoinform. 2010, 12, 201-207. [CrossRef]

15. Dawelbait, M.; Morari, F. Monitoring desertification in a Savannah region in Sudan using Landsat images and spectral mixture analysis. J. Arid Environ. 2012, 80, 0-55. [CrossRef]

16. Liu, H.J.; Zhou, C.H.; Cheng, W.M.; Long, E.; Li, R. Monitoring sandy desertification of Otindag Sandy Land based on multi-date remote sensing images. J. Acta Ecol. Sin. 2008, 28, 627-635.

17. Liu, Y.Z.; Alimujiang, K.; Abudumijiti, A. Remote sensing monitoring of dynamic change of desertification in typical areas along the Silk Road Economic Zone. J. Sci. Soil Water Conserv. 2017, 15, 1-8.

18. Wang, H.B.; Ma, M.G.; Geng, L.Y. Monitoring the recent trend of aeolian desertification using Landsat TM and Landsat 8 imagery on the north-east Qinghai-Tibet Plateau in the Qinghai Lake basin. J. Nat. Hazards 2015, 79, 1753-1772. [CrossRef]

19. Lamchin, M.; Lee, J.Y.; Lee, W.K.; Lee, E.J.; Kim, M.; Lim, C.H.; Choi, H.A.; Kim, S.R. Assessment of land cover change and desertification using remote sensing technology in a local region of Mongolia. J. Adv. Space Res. 2016, 57, 64-77. [CrossRef]

20. Cristina, N.M.; Abigail, M.S.V. Assessing the progress of desertification of the southern edge of Chihuahuan Desert: A case study of San Luis Potosi Plateau. J. Geogr. Sci. 2017, 27, 438.

21. Gao, L.S. Development of the Mongolian railway. J. Compr. Transp. 1996, 8, 38-40.

22. Wei, Y.J.; Zhen, L.; Liu, X.L.; Ochirbat, B. Land use change and its driving factors in Mongolia from 1992 to 2005. J. Chin. J. Appl. Ecol. 2008, 19, 1995-2002.

23. Guo, Y.G.; Yu, X.F.; Jiang, D.; Wang, S.K.; Jiang, X.S. Study on forest classification based on object oriented techniques. J. Geo Inform. Sci. 2012, 14, 514-522. [CrossRef]

24. Mongolian Statistical Information Service. Available online: www.1212.mn (accessed on 25 October 2018).

25. Ma, Y.Y.; Zhang, C.X.; Zhang, J.C.; Xie, G.D.; Zhang, L.M. Research on object-oriented classification Method assisted with NDVI/DEM in extracting cassava: Taking wuming county for example. J. Geogr. Geo Inform. Sci. 2015, 31, 49-53.

26. Yue, X.X. Study on the Flora of Seed Plants in the Mongolian Plateau. Ph.D. Thesis, Inner Mongolia Agricultural University, Huhehaote, China, 2011.

27. Cao, X.M.; Wang, J.L.; Feng, Y.M. An improvement of the Ts-NDVI space drought monitoring method and its applications in the Mongolian Plateau with MODIS, 2000-2012. J. Arab. J. Geosci. 2016, 9, 1-14. [CrossRef]

28. Ren, C.S.; Ye, H.C.; Cui, B.; Huang, W.J. Acreage estimation of mango orchards using object-oriented classification and remote sensing. J. Resour. Sci. 2017, 39, 1584-1591.

29. Wang, J.L.; Cao, X.M.; Wang, Z.M. Land Cover and Environmental Change in Mongolia; Meteorological Press: Beijing, China, 2018; p. 22.

30. Wang, J.L.; Cheng, K.; Zhu, J.X.; Liu, Q. Development and pattern analysis of Mongolian land cover data products with 30 meters resolution. J. Geo Inform. Sci. 2018, 20, 1263-1273.

31. Bo, C.G. NDWI-A Normalized difference water index for remote sensing of vegetation liquid water from space. J. Remote Sens. Environ. 1996, 58, 257-266.

32. Tobu, N.C.; David, A.; Riziley. On the relation between NDVI, fractional vegetation cover, and leaf area index. J. Remote Sens. Environ. 1997, 62, 241-252.

33. Kindu, M.; Schneider, T.; Teketay, D.; Knoke, T. Land use/land cover change analysis using object-based classification approach in munessa-shashemene landscape of the Ethiopian Highlands. J. Remote Sens. 2013, 5, 2411-2435. [CrossRef]

34. Ci, L.J. Understanding on the term of "Desertification". J. Chin. Sci. Technol. Terms J. 2000, 2, 11-13.

35. Zhang, H.; Shen, W.S.; Zhang, H.; Zhou, C.X.; Cao, X.Z. Impacts of construction of Qinghai-Tibet railway on landscape pattern. J. Ecol. Rural Environ. 2004, 20, 20-23.

36. Ding, M.J.; Zhang, Y.L.; Shen, Z.X.; Liu, L.S.; Zhang, W.; Wang, Z.F.; Bai, W.Q.; Zheng, D. Land cover change along the Qinghai-Tibet Highway and Railway from 1981 to 2001. J. Geogr. Sci. 2006, 16, 387-395. [CrossRef]

37. Tian, J.; Wang, J.L.; Li, Y.F.; Zhou, Y.J.; Guo, H.H.; Zhu, J.X. Land cover classification in Mongolian Plateau based on decision tree method: A case study in Tov Province, Mongolia. J. Geo Inform. Sci. 2014, 16, 460-469.

38. Zhou, X.Y. Impact of Land Use Change and Climate Change on Vegetation in Mongolian Plateau. Master's Thesis, Beijing Forestry University, Beijing, China, 2014. 
39. China Daily. A passenger train derailed in Mongolia. 2018. Available online: http://cnews.chinadaily.com. cn/2018-08/13/content_36753053.htm (accessed on 20 August 2018).

40. Shi, Y.L. The study on grazing system of grassland animal husbandry in Mongolia. Master's Thesis, Inner Mongolia University, Huhehaote, China, 2009.

41. Li, J.; Hou, X.H. Risk prevention and control strategy analysis of Heilongjiang province's response to the construction of "China-Mongolia-Russia" economic corridor. J. Cognit. Pr. 2016, 4, 107-113.

42. Ao, R.Q.; Na, L. Mongolia's ecological environment and its regional cooperation in northeast Asia. J. Financ. Econ. Theory 2010, 3, 34-37.

(C) 2019 by the authors. Licensee MDPI, Basel, Switzerland. This article is an open access article distributed under the terms and conditions of the Creative Commons Attribution (CC BY) license (http://creativecommons.org/licenses/by/4.0/). 